\title{
Reduction of the Shadow Spacer Effect using Reverse Electrodeionization and its Applications in Water Recycling for Hydraulic Fracturing Operations
}

\author{
Alexander Lopez, Hailey Dunsworth, Jamie Hestekin* \\ Ralph E. Martin Department of Chemical Engineering, University of Arkansas \\ "Corresponding Author: Email: jhesteki@uark.edu. \\ Postal Address: 3202 Bell Engineering Center, Fayetteville, AR 72701
}




\section{ABSTRACT}

Reverse electrodialysis (RED) is an electrically driven process for the extraction of usable energy from the Gibbs free energy of mixing. Past research efforts have focused on the improvement of power density through higher voltages, large cell numbers, and overall reduction of stack resistance, yet the process remains far from optimized. One of the principal problems is the shadow spacer effect where limited conductivity near the spacer decreases the amount of electrical transport. We have improved this technology by incorporating ion exchange wafers in each cell, shortening the diffusion pathways, limiting the shadow spacer effect, and obtaining net power densities of approximately $0.32 \mathrm{~W} / \mathrm{m}^{2}$ for reverse electrodeionization (REDI) compared to 0.01 $\mathrm{W} / \mathrm{m}^{2}$ for the RED case. Further, we have found that applying voltage to the system gives an increase in the overall power extraction efficiency due to wafer optimization and the non-ohmic behavior at low voltages. This is the first study incorporating electrodeionization techniques in RED systems. We also investigated the use of REDI in hydraulic fracturing and obtained a net power density of approximately $0.79 \mathrm{~W} / \mathrm{m}^{2}$ using produced water. This technology could be utilized for processing of produced water from hydraulic fracturing operations to provide some of the power used at the well site (when mixing with fresh water for re-fracking) with no greenhouse gas emissions. Using REDI at fracking sites, an industrial process that has been mired by environmental concerns can take positive steps toward developing and adopting sustainable practices.

KEYWORDS Reverse electrodialysis, Ion Exchange Membranes, Hydraulic Fracturing, Electrodeionization, Alternative Energy 
Graphical Abstract:

Hydraulic Fracturing

\& Water Recovery

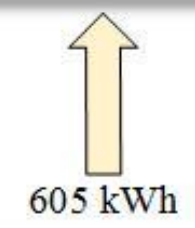

Fracking Fluid

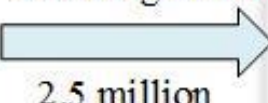

gallons

Reverse

Electrodeionization

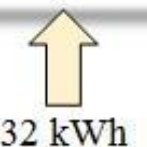

Water

replenishment

2.5 million

gallons

$\approx 1.9$ million

liters

Freshwater

Reverse Electrodeionization holds great potential for use in hydraulic fracturing as a means to power system operations and water recovery technology. 


\section{Introduction}

Recently, salinity-gradient energy sources have become competitive options in the alternative energy sector [1,2]. Salinity-gradient energy, or "blue energy" [3], is defined as the energy available from mixing two aqueous solutions of different salinities, and has a total global potential for power production of $1.4-2.6 \mathrm{TW}$ or as many as 3,000 coal fired power plants [2,410]. When "produced water" from fracking is returned to the surface, it contains a high concentration of salts, thus when $1 \mathrm{~m}^{3}$ of salt water is mixed with $1 \mathrm{~m}^{3}$ of fresh water for later reuse a maximum potential of $10 \mathrm{MJ}$ is available to extract as usable power from Gibbs free energy of mixing [11-13]. However, no studies have been conducted relating this energy potential to the fracking industry. The fracking industry is an ideal application for reverse electrodialysis (RED) because brine solutions and freshwater are found in large quantities at each well site. Not only does our research focus on augmenting the RED process for improved power production, but also it takes this a step further by providing a sustainable solution some environmental hydraulic fracturing concerns.

\subsection{Reverse Electrodialysis}

Reverse electrodialysis is an electrochemical process driven by the concentration difference between feed streams (diluate and concentrate) that are separated by ion selective membranes, creating an ion flux as cations and anions migrate across the membranes $[1,3,14]$. Through a redox reaction which occurs at the electrodes, this ion flux is converted directly into an electric current $[3,15]$. Several designs for RED systems have been considered, generally consisting of alternating cation and anion exchange membranes separated by spacers and terminated with an electrode at each end [14-16]. In multi-cell systems, a serial configuration is used to maximize voltage potential and power generation [17]. Homogeneous ion exchange membranes are used for their high permselectivity for ions with opposing charge while repelling 
ions with like charge [18]. Previous research has found solutions to some limitations in RED including those for the spacer shadow effect [19-21], fouling [6], and resistance [10]. Balster et al. investigated the use of profiled membranes and spacer-free systems for increased mass transfer and reduced cell resistance $[22,23]$. Dlugoluki et al. found that the spacer shadow effect can reduce the overall energy recovered by $30-40 \%$, representing a significant loss in total energy that must be recovered in order to make RED systems attractive for energy production [19].

In a traditional RED setup, the low conductivity of the liquid in the diluate chamber results in limited ionic transport. As a result, the electrical resistance in the diluate chamber is often the dominant restriction $[24,25]$. Therefore, the focus of this research is to provide a working solution to limited ion diffusion and energy production by applying principles of electrodeionization (EDI) [26-28] in hopes of reducing the shadow spacer effect and increasing the overall current density. A wafer is made by binding ion exchange resins with a polymer [26] and inserting it into an electrodialytic cell in place of a flow spacer to stimulate ionic transport. This concept can be used to not only reduce the spacer-shadow effect but also improve the ion transport restrictions caused by low solution conductivity. Thus, this study investigated the improvement of energy production and power density in an RED system through the use of ion exchange resin-wafers in solution compartments. This work differs than previous studies in that the wafer is used as a conductive spacer to reduce the spacer-shadow effect and cell resistance similar to the effects seen in EDI.

\subsection{Technology Implications for Produced Water from Hydraulic Fracturing}

Hydraulic fracturing has become widely utilized as a means for extracting natural gas and oil previously thought unobtainable. Each well site is horizontally drilled, and injected with 1216 million liters of "fracking fluid" (water with sand and chemical additives), under high pressure to crack the formation thus increasing the permeability of the surrounding rock enabling enhanced gas and oil flow to the well [29]. Following the fracturing process, $20-100 \%$ [11,29] of this fluid 
returns to the surface as "produced" water containing contaminants, mainly dissolved salts,. Because of the high concentration of salts the produced water has little value and is commonly disposed of in deep injection wells. However, it is suspected that this has contributed to recent seismic events in addition to permanently removing water from the ecosystem [30-32]. As a result, the need for devising an alternative method for handling produced water has become both environmentally and economically pressing.

Although RED won't treat produced water, the potential power recovery is attractive to those in hydraulic fracturing. To begin produced water recovery in a system utilizing RED, a series of pretreatment regimens are implemented in order to remove non-ionic contaminants such as oil components, chemicals included in the fracking fluid, and foulants. Once these have been removed, RED technology can be used to harness the Gibbs free energy of mixing ions between this partially treated produced water and a freshwater feed with the purpose of replenishing the water that could not be recovered from water clean-up. This extracted energy can then be used to power ongoing processes or stored in a battery for later use in subsequent fracking process when needed. The resulting water solution output from the RED system can then be recycled back into the hydraulic fracturing process. This revolutionary approach allows for the recycle of water and production of energy.

\section{Materials and Methods}

We designed an innovative reverse electrodeionization system (REDI) system that utilized EDI techniques to minimize system resistance. This system was tested with varying numbers of cell pairs (1-cell system, 5-cell system, 10-cell system). Membranes were separated by custom hybrid spacer-gaskets to minimize cell length. In a traditional EDI system, a flow spacer is used to move fluid across the membrane while a rubber gasket is placed between each spacer to ensure a water tight seal. For this study, we used a specialized plastic to act as both the flow spacer and 
sealing gasket to reduce overall cell thickness. Each one measured $500 \mu \mathrm{m}$ thickness. Fumatech FKS-30 and FAS homogeneous ion exchange membranes were used for experimentation. A schematic of the general system configuration is shown below in Figure 1.

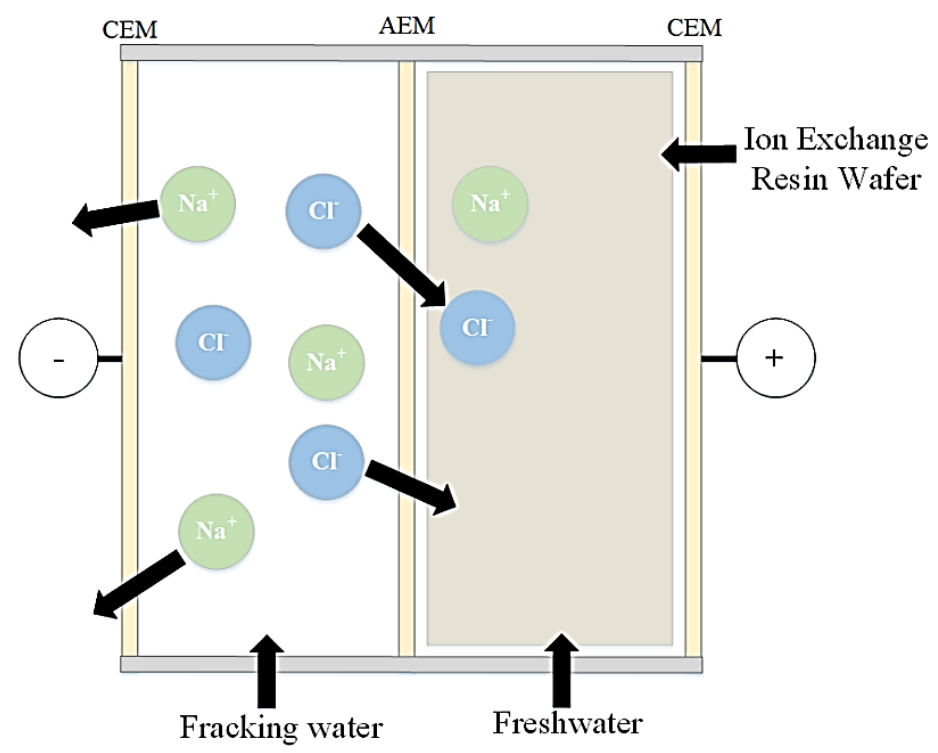

Figure 1. Diagram of RED Cell using resin technology. Membranes are spaced within the cell, and compartments alternate between freshwater and fracking/brackish water. Ion exchange resin wafers are placed in freshwater compartments to improve solution electrical conductivity. Rinse compartments not shown.

\subsection{Wafer Casting}

Ion exchange wafers used in experimentation were composed of both anion and cation exchange resins (Amberlite ${ }^{\circledR}$ IRA-400(Cl-) and Amberlite ${ }^{\circledR}$ IR120 $\left(\mathrm{Na}^{+}\right)$form ion exchange resins), polymer (polyethylene powder, $500 \mu \mathrm{m}$ ), and sucrose. A custom iron cast was constructed that measured $127 \times 127 \mathrm{~cm}$ in diameter. Each batch of wafer ingredients were mixed in a 46:15:10 gram ratio of ion exchange resin, sugar, and polymer developed in a previous study [26]. The composition was then mixed at a rate of $300 \mathrm{rpm}$ for 5 seconds using a FlackTek Inc. SpeedMixer ${ }^{\mathrm{TM}}$ (model: DAC $150 \mathrm{SP}$ ) to ensure uniformity. Wafer material was placed in the cast, and then inserted into a Carver press (model 3851-0) at $10,000 \mathrm{psi}$ and $237^{\circ} \mathrm{F}$ for 90 minutes, followed by a 20 minute cooling period via pressurized air treatment. After cooling, the cast was removed, and wafer carefully extracted. Once completed, the wafer is cut to fit into our REDI 
system and placed in the freshwater compartment in lieu of a turbulence mesh. Figure 2 shows an image of the resulting wafer structure. The resin and sucrose become bound by the polymer, and following a soak in a water solution, the sucrose dissolves leaving a porous wafer. This allows the REDI solutions to flow around and through the wafer similar to a turbulence spacer in traditional systems. The novelty of our wafer comes from its improvement of ion transport through a drastically reduced diffusion path length for ions. At voltages above $1.5 \mathrm{~V}$, water splitting will occur within the REDI system, and the generated ions eliminate the potential for surface attachment of other monovalent and divalent ions in solution, improving ion mobility and diffusion rates.

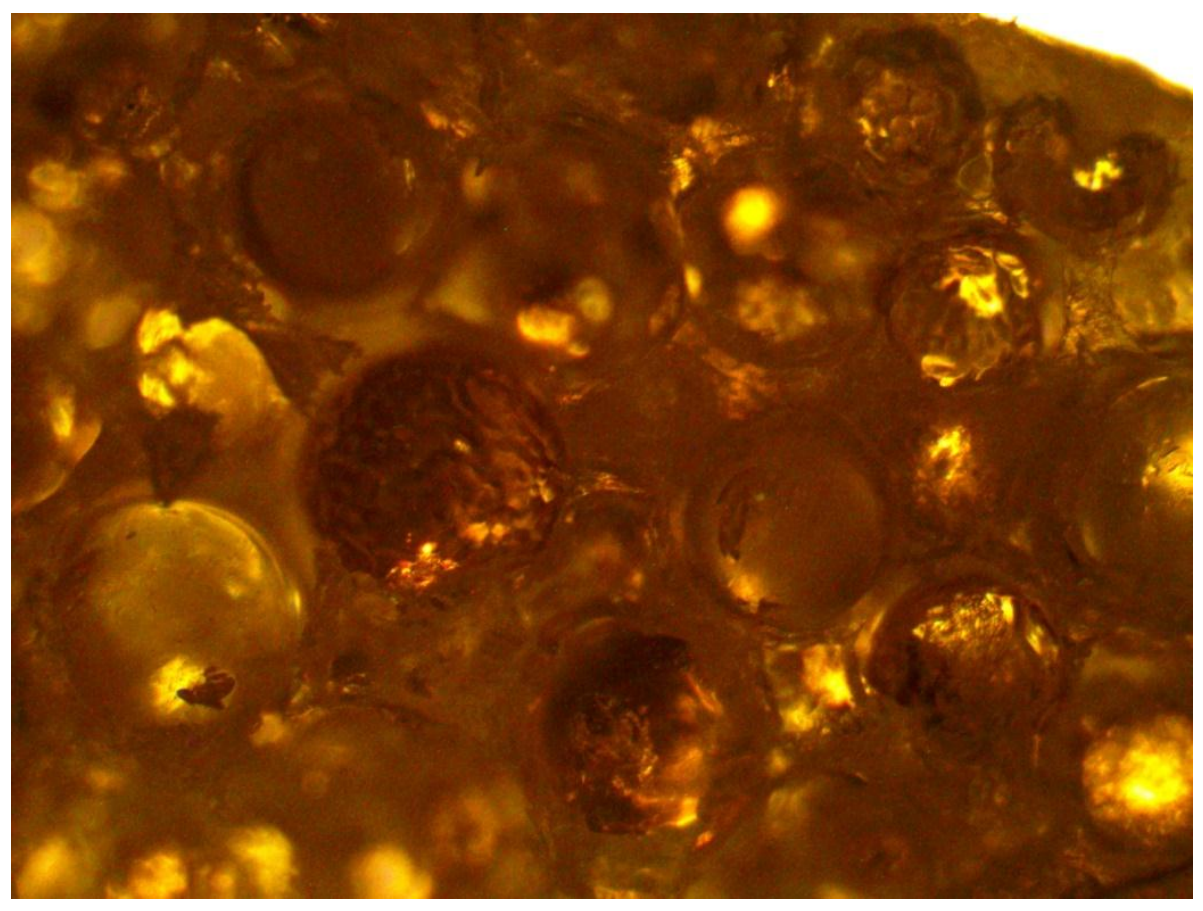

Figure 2. Microscopic Image of Resin Wafer used in REDI. A. Spherical resins partially encased by polymer binder. Active area should be maximized to ensure proper wafer activity.

\subsection{Feed Water Concentrations}


Experiments were conducted with simulated saltwater and freshwater feeds at $30 \mathrm{~g} / \mathrm{L}$ and $0.1 \mathrm{~g} / \mathrm{L} \mathrm{NaCl}$, respectively. All feed waters were pumped through the cell using peristaltic pumps at approximately $50 \mathrm{~mL} / \mathrm{min}$ at room temperature and linear velocity of approximately $25 \mathrm{~cm} / \mathrm{min}$. Initial and final conductivities of concentrate and dilute feed streams were measured in addition to the open circuit voltage potential. Experiments were also conducted using fracking water obtained from an Oklahoma well site. Table 1 shows the compositions of the main contaminants present in the Oklahoma produced water. All hydraulic fracturing simulations performed were based on voltages obtained in these tests. Additionally, all experiments were performed in triplicate to ensure data accuracy and repeatability. Also, it is important to note that although bicarbonate fouling has been a problem with EDI systems we have not seen any evidence of this in fracking water with long term testing showing no particulate fouling.

Table 1. Characteristics of produced water from Oklahoma hydraulic fracturing site.

\begin{tabular}{|c|c|}
\hline & Oklahoma Fracking Water \\
\hline $\mathrm{pH}$ & 6.15 \\
\hline Turbidity (NTU) & 2,200 \\
\hline COD $(\mathrm{ppm})$ & 54,100 \\
\hline TSS $(\mathrm{ppm})$ & 21,300 \\
\hline Conductivity $(\mathrm{mS} / \mathrm{cm})$ & 162 \\
\hline Sodium $(\mathrm{ppm})$ & 43,000 \\
\hline Calcium $(\mathrm{ppm})$ & 8,100 \\
\hline
\end{tabular}

\subsection{Analytical Measurements: Electrochemical}

Voltage and current readings were taken for both traditional RED conditions and our REDI design. These were obtained using both a digital multimeter (Klein Tools) and potentiostat (Amel model 2053). Once the REDI stack was set up for a specific set of conditions, fluid was pumped through the stack, and voltage readings were measured directly from the multimeter with fluid flow being the only source of ionic movement. Once an average voltage was obtained per cell pair from a single cell stack, the potentiostat was used to simulate multi-cell systems greater than 10 
cells. This comparison is presented in Figure 3. A range of voltages were applied to the stack and current measurements were obtained. It was then possible to calculate the system resistance and the overall power density capability of the stack. The passive current created during testing with the potentiostat was subtracted from the current generated from the solution concentration gradient in order to obtain gross power density.

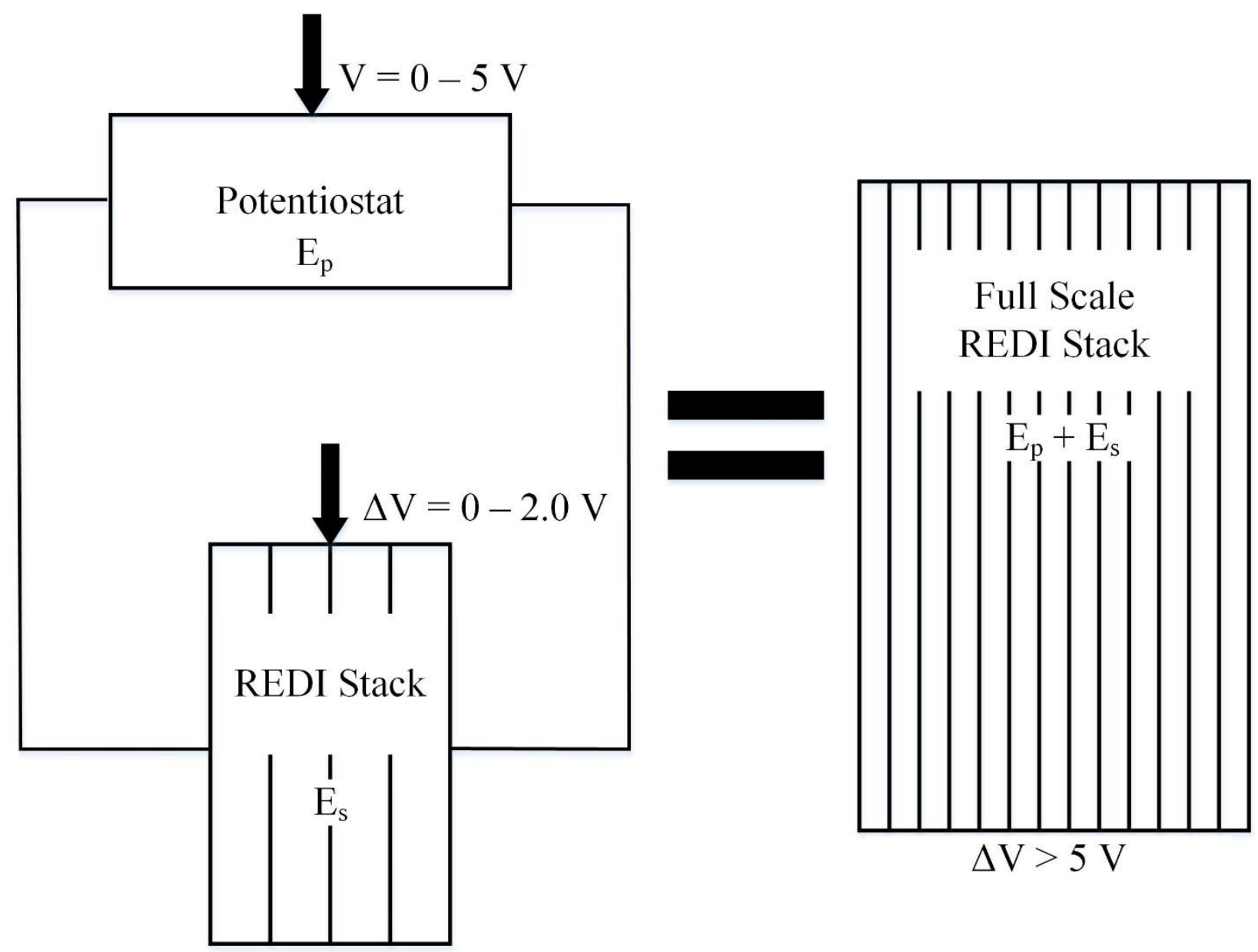

Figure 3. Potentiostat Comparison. A potentiostat was used in order to boost voltage through the system similar to a full-scale REDI system. Note. All power density calculations were adjusted to account for the passive current added by the potentiostat. The power densities recorded were generated by the freshwater and simulated water solutions.

\subsection{Mathematical Theory}

To simulate the process scale-up, the following equations were used to obtain the resistance of each cell pair and electrode at a specified voltage: 


$$
R_{\text {cell }}+R_{\text {electrode }}=R_{\text {total }}
$$

where $R_{\text {cell }}$ was the resistance of a single cell and $R_{\text {electrode }}$ was the combined resistance of the electrodes. In this study, stainless steel electrodes were used and $\mathrm{R}_{\text {electrode }}$ was measured to be low $\left(<1 \Omega \mathrm{cm}^{2}\right)$, so it can be omitted from equation 1 . Once these values were obtained, it was necessary to find the number of cell pairs needed to generate a given voltage. This was determined using equation 2.

$$
\frac{V_{\text {applied }}}{V_{\text {cell pair }}}=N
$$

where the $\mathrm{V}_{\text {cell pair }}$ was the voltage obtained from a single cell pair using RED and $\mathrm{V}_{\text {applied }}$ was the theoretically generated voltage through applying it to the RED system. The cell pair voltage was identified from the multimeter data, and the applied voltage was varied from 0.2-4.5 $\mathrm{V}$ using the potentiostat. This number was multiplied by $\mathrm{R}_{\text {cell }}$ to obtain the total resistance per stack. Power density was then calculated from equation 3 .

$$
P=\frac{V_{\text {applied }}^{2}\left(R_{\text {load }}\right)}{2\left(R_{\text {total }}+R_{\text {load }}\right)^{2}}=\frac{V_{\text {applied }}^{2}}{8 R_{\text {total }}}
$$

Previous studies have demonstrated that the maximum power generated from an RED stack occurs when a load applied the system equals the stack resistance [5]. To find power density in units of $\mathrm{W} / \mathrm{m}^{2}$, the last expression is divided by the total active membrane area, found by multiplying the number of membranes used by the active area. For this research, the active area was $10 \mathrm{~cm}^{2}$.

\section{Results and Discussion}

\subsection{Voltage Potential}

Voltage potential showed the maximum power density that can be obtained based on an REDI system under a given load. This set of experiments was performed using a multi-cell RED stack, and run with simulated fracking solution of $14 \% \mathrm{NaCl}(140 \mathrm{~g} / \mathrm{L})$ and $0.1 \% \mathrm{NaCl}(1 \mathrm{~g} / \mathrm{L})$ salt 
solution in the concentrate and diluate feed stream respectively. Additionally, water from an Oklahoma fracking site was used to confirm the voltage output from this application. Before REDI experiments, produced water from hydraulic fracking entering the REDI apparatus had undergone nanofiltration pretreatment to remove all suspended solids and divalent ions from the water, maximizing voltage potential. It was found that an average of $181 \mathrm{mV}$ was produced per cell pair. When simulated seawater at $3 \% \mathrm{NaCl}(30 \mathrm{~g} / \mathrm{L})$ was tested with $0.1 \% \mathrm{NaCl}(1 \mathrm{~g} / \mathrm{L})$ solution, the output voltage was $150 \mathrm{mV}$. These values were later used for power density calculations.

\subsection{Gross Power Density}

Gross power density is the maximum amount of power that can be obtained from an RED system before pumping losses are taken into consideration. Using thicknesses such that we are using $(0.485 \mathrm{~mm}$ as compared to our $0.5 \mathrm{~mm})$ the maximum gross power density has been shown to be $0.6 \mathrm{~W} / \mathrm{m}^{2}$ [7]. In order to obtain gross power density, several sets of experiments were performed to simulate a multi-stack design for high voltage operation ranging from 0.2 to $5 \mathrm{~V}$. Current and power density calculations were then carried out and corrected for non-ohmic behavior caused by the presence of the ion exchange wafers by subtracting out the power requirements for wafer regeneration $[27,33]$. Thus, we are adding power to the system, in terms of an applied voltage, and measuring the additional power generated by taking a concentration gradient (such as $14 \%$ salt to $0.1 \%$ salt) and subtracting the system with no concentration gradient (such as $1 \%$ salt on both sides). This is the first attempt we know of in literature to combine adding a passive current to increase the power density in an RED system.

Figure 4 shows the gross power density obtained for both traditional and wafer-enhanced conditions. The highest power generation was $0.9 \mathrm{~W} / \mathrm{m}^{2}$ for the wafer enhanced system using fracking solutions while simulated seawater resulted in a power density of $0.43 \mathrm{~W} / \mathrm{m}^{2}$. When no wafers were used, the power density obtained was $0.12 \mathrm{~W} / \mathrm{m}^{2}$. This clearly shows that the wafer is 
helping to eliminate the shadow spacer effect. Dlugolecki et al. found similar results when applying conductive spacers to eliminate the spacer shadow effect with a three-fold increase in power density; however, their results showed higher power densities due to their use of $180 \mu \mathrm{m}$ spacers [19]. The power densities we obtained are less than literature values of the same thicknesses $\left(0.12 \mathrm{~W} / \mathrm{m}^{2}\right.$ compared to $\left.0.6 \mathrm{~W} / \mathrm{m}^{2}\right)$ due to these systems having lower stack resistance due to the use of specialty anion and cation exchange membranes as well as higher flowrates [7]. For voltages below $1.5 \mathrm{~V}$, power output was very low $\left(<0.05 \mathrm{~W} / \mathrm{m}^{2}\right)$. When $1.5 \mathrm{~V}$ was reached, wafer activation occurred (i.e., water splitting) and significant increases in gross power density were observed. Wafer activation refers to the minimum voltage required for water splitting so some of the power available in Gibbs free energy is going to this generation rather than becoming recoverable. Even though this water splitting reduces the amount of power recoverable, it does increase the power density due to faster transport and may help reduce capital costs due to high costs of membranes and low power densities. This also adds to the non-ohmic resistance seen in the REDI system and evidenced in other RED studies [34]. This is the first known study where REDI is shown to increase the power density in a RED system. 


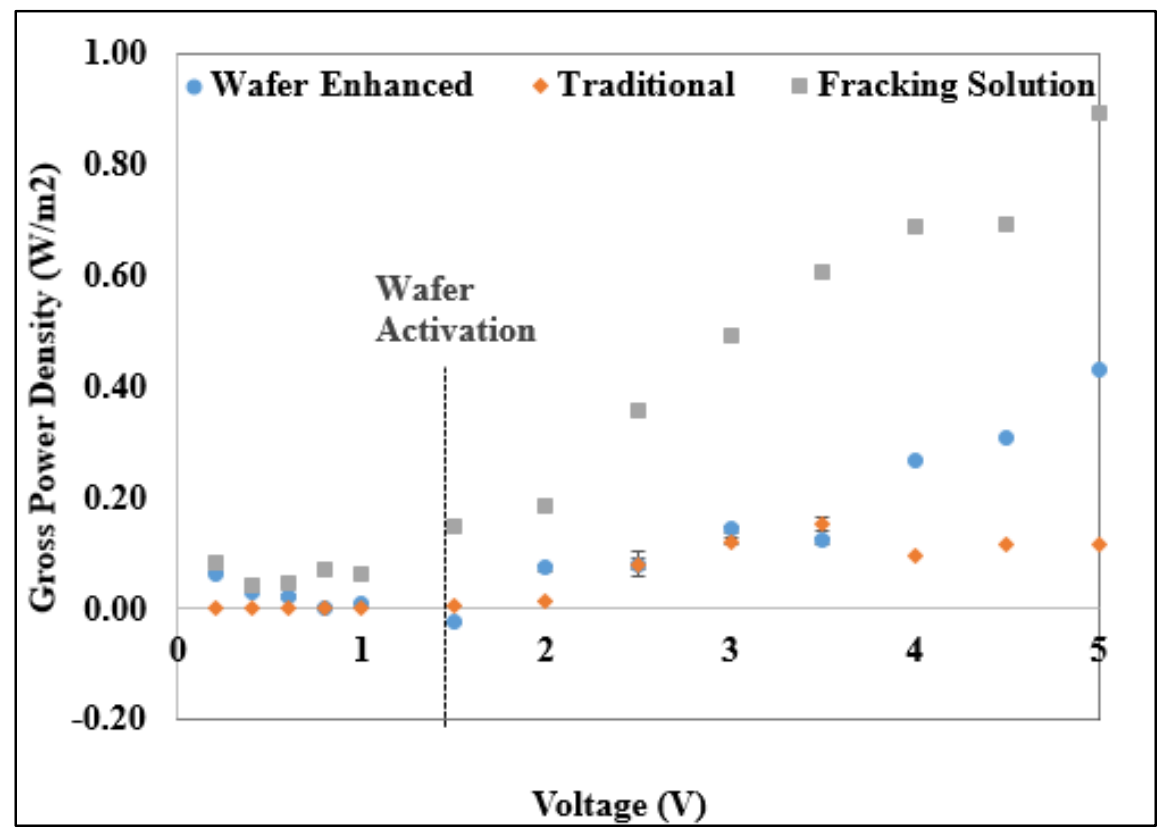

Figure 4. Gross Power Density. Gross power density of the REDI stack for traditional and wafer-enhanced REDI conditions. Dashed lines demonstrate theoretical performance curves for each condition.

Simulated power densities for the traditional system show an ideal case; however, there are several system hindrances that would result in lower than expected power yield with traditional RED. At low voltages, ion transport is limited by the high resistance of the freshwater stream, so reaching a high voltage potential can be very difficult due to the large resistance inherent to the system. This resistance limitation is shown in Figure 5. The increase in resistance between 1-2 V for the traditional system occurred for every experimental trial conducted. Also in high voltage systems, water splitting can result in severe damage to the ion exchange membranes in traditional RED; however, the wafer enhanced case prevents membrane damage and promotes wafer regeneration $[26,27,33]$. 


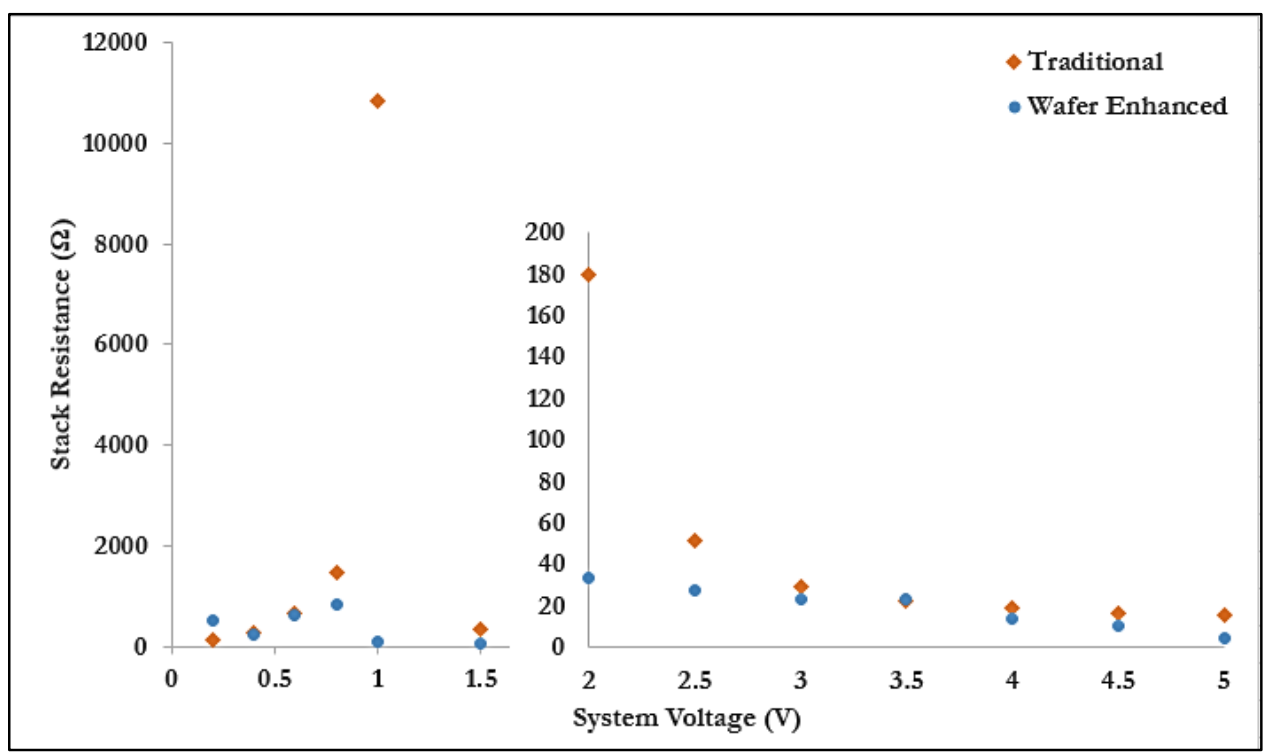

Figure 5. REDI Stack Resistance. Comparison of resistance between traditional and waferenhanced conditions.

\subsection{Net Power Density}

For an accurate representation of possible power density output, energy consumption due to pumping losses must be considered. Taking into account the total pressure drop across the system, the energy losses due to pumping were $0.11 \mathrm{~W} / \mathrm{m}^{2}$ for all tests. This was calculated from the pressure drop observed during testing of all experiments, which had negligible resistances between experimental conditions at this scale. In larger systems, the wafers in REDI will have a significant impact on pressure drop and must be considered when determining net power density. Subtracting energy consumption from gross power density numbers yields the net power density, or what would be generated for use in practical applications. Figure 6 shows the net power density of our REDI system. It is important to note that the energy losses in these studies are large compared to the total power generated. In scaled-up systems, losses due to pumping relative to energy generation will greatly diminish. 


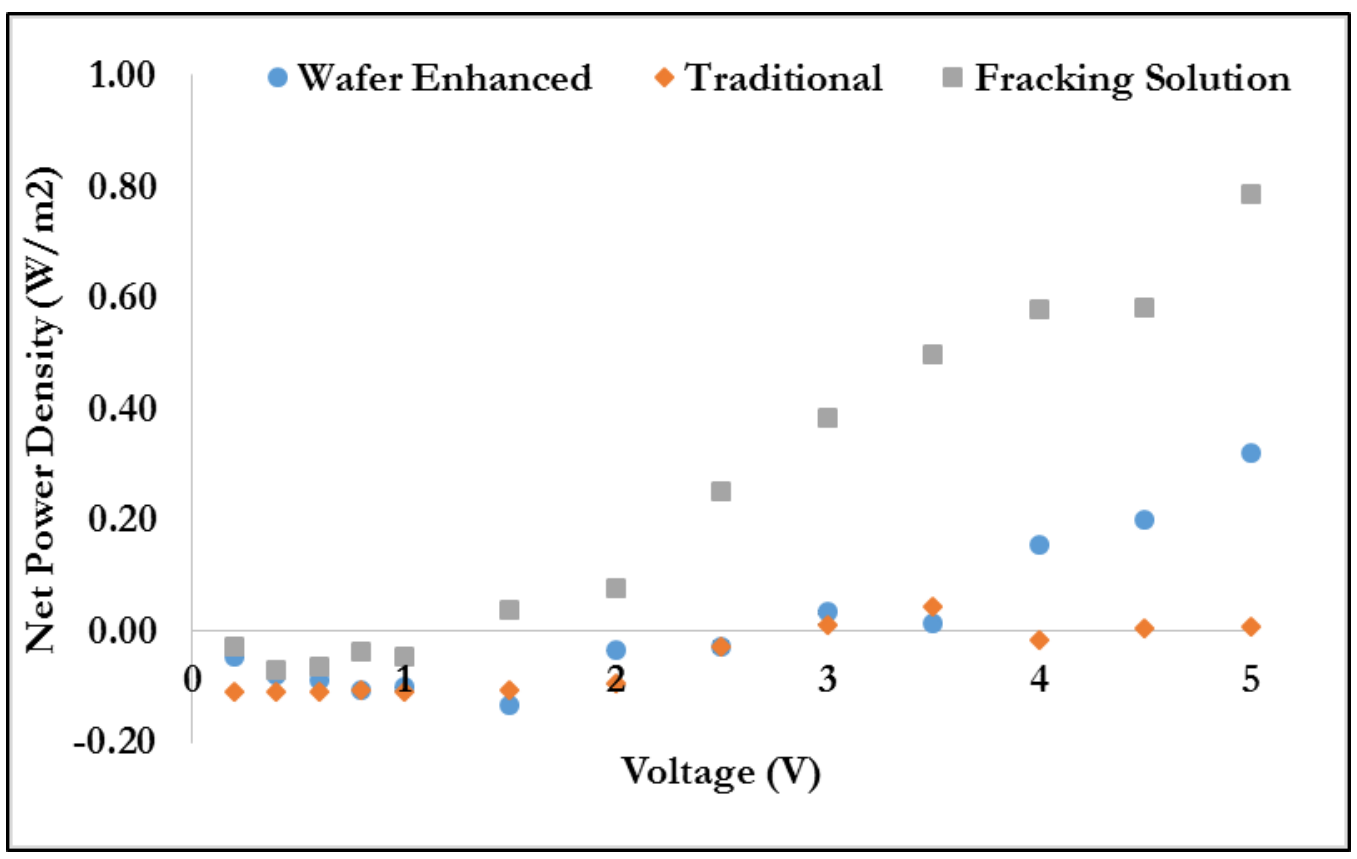

Figure 6. Net Power Density. Net power density of wafer enhanced and traditional REDI systems correcting for pumping, passive current added during testing, and wafer regeneration.

The net power density was $0.79 \mathrm{~W} / \mathrm{m}^{2}$ for the wafer enhanced system running with fracking water and $0.32 \mathrm{~W} / \mathrm{m}^{2}$ for the wafer enhanced system simulated seawater was used. The traditional system had a net power density of $0.01 \mathrm{~W} / \mathrm{m}^{2}$. At voltages below $1.5 \mathrm{~V}$, low power output is observed as seen in Figure 4 and 6 above. At the onset of water splitting, we observe a negative power density for the wafer enhanced system resulting from the power required for wafer regeneration and pumping. At higher voltages, stack resistance is greatly reduced (Figure 5) and the wafer enhanced system outperforms the traditional RED system. This is a result of wafer performance and a decrease in traditional system performance directly resulting from increased water splitting. In order to obtain higher power densities, larger systems as well as thinner membranes and solution spacers are needed. As power density increases, losses due to pumping and wafer regeneration become less significant. Theoretical predictions based on lab data suggest that power densities between $2-5 \mathrm{~W} / \mathrm{m}^{2}$ are possible with an optimized system. Coupling this technology with water recycle may prove to be a key component in commercialization of this 
technology. Using this system in the hydraulic fracturing industry can reduce the amount of energy and resources required for oil and natural gas extraction and provide the means for larger systems.

\subsection{Implications for the Fracking Industry}

Research investigating the treatment and recycle of this produced water for re-use at other well sites has been conducted [35,36]. In one case, a nanofiltration process was used to recycle produced water and then freshwater was reintroduced to the process through RED. Through nanofiltration and RED, water recoveries greater than $80 \%$ are possible. Previous studies have shown that mixing $1 \mathrm{~m}^{3}$ of freshwater and $1 \mathrm{~m}^{3}$ of seawater can produce up to $1.8 \mathrm{MJ}$ [37]. Assuming a theoretical energy extraction efficiency of approximately 50\% and correcting for salt

content of produced water, our process can recover $0.44 \mathrm{~kJ} / \mathrm{gal}$. This results in a potential of approximately $600 \mathrm{kWh}$ that can be produced in an RED system mixing treated produced water and freshwater that is added to account for water losses in previous hydraulic fracking operations and during water treatment. Economic calculations on an average fracking site (assuming 5 million gallons used and $60 \%$ water recovery from drilling) show an average increase in revenue over 300,000 dollars a year per well making the technology environmentally friendly and economically attractive. A diagram of the proposed treatment cycle is shown in Figure 7 below. 


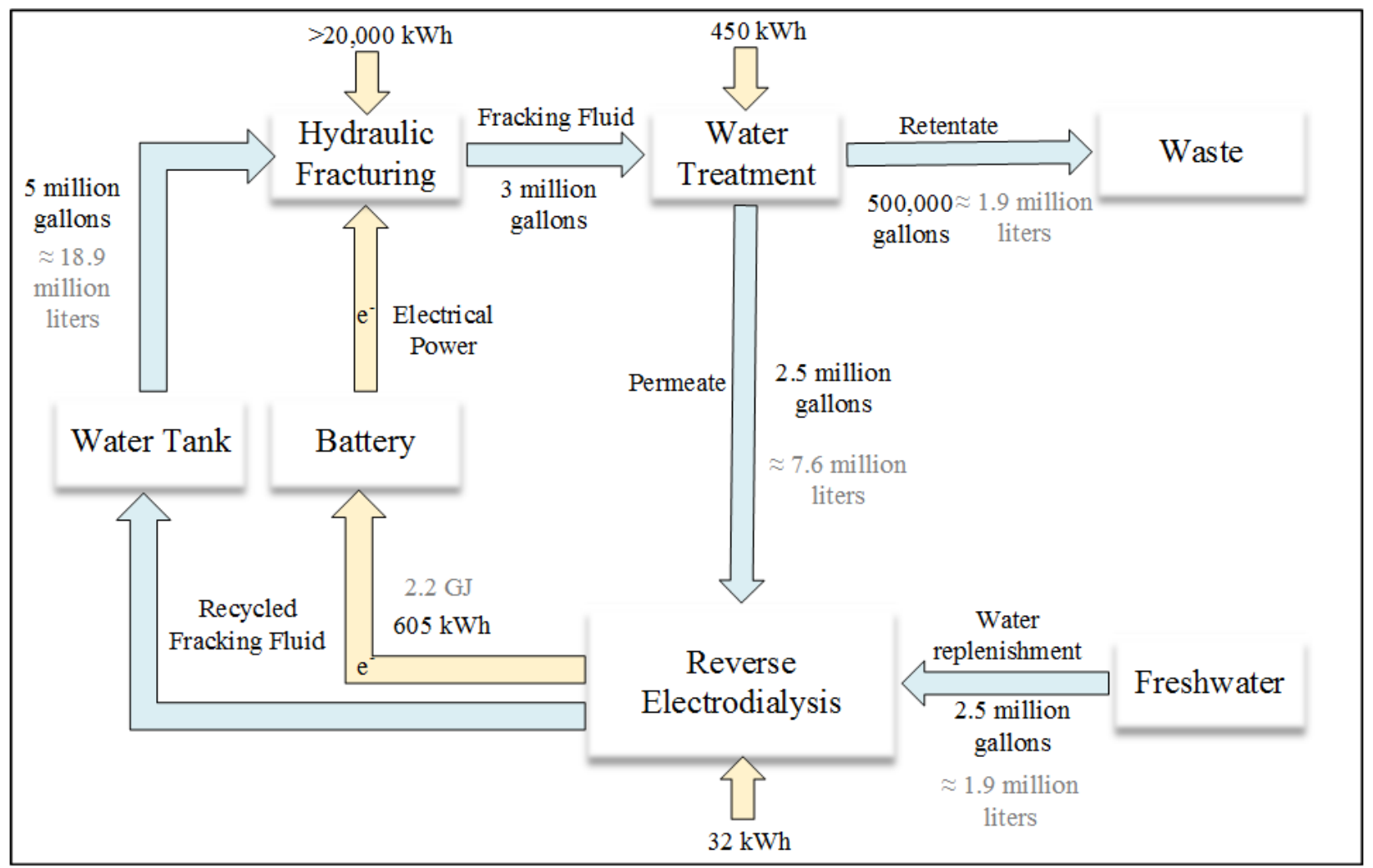

Figure 7. Enhanced Produced Water Treatment Cycle. Treatment cycle consisting of both traditional and advanced pretreatment techniques, while implementing RED technology.

The process water leaving the hydraulic fracturing system will be treated for recycle. However, some of the water cannot be recovered and requires replacement. By controlling the mixing of this freshwater feed with the treated fracking water, RED systems can be implemented to provide useful power for fracking operations. This will not result in a net positive energy balance; however, this system will reduce the overall energy demand for hydraulic fracturing operations. The resulting water energy recovered can then be used in additional hydraulic fracking operations or stored via a battery for later use, reducing the overall water and energy demands.

\section{Conclusion}

Salinity-gradient energy is one of the most promising untapped potentials in the alternative energy sector, with reverse electrodialysis as a front-runner among the extraction technologies 
currently being explored. Through this research the limitations in RED caused by high stack resistance have been mitigated. With the use of REDI, system resistance is dramatically decreased, and thus a substantial increase in power density is observed. This technology also serves as a bridge to close the gap between lab-scale and practical applications. It allows for the system to operate effectively at higher voltages, and uses the effects of water-splitting that occur to an advantage. The dominant economic factor of using RED as an alternative energy source is the price of the membranes. With this improved application for wafer technology in the REDI process, it is possible to reach power densities in the range of $2-5 \mathrm{~W} / \mathrm{m}^{2}$ depending on the system configuration, water quality, and other constraints. Additionally, more research on developing thinner wafers is crucial to the improvement of net power densities. Finally, this study considered incorporating REDI technology into hydraulic fracturing. Using REDI, energy can be produced for fracking operations with water recycle systems for a more environmentally friendly and economic hydraulic fracking process.

\section{Acknowledgements}

The authors would like to acknowledge the Ralph E. Martin Department of Chemical Engineering at the University of Arkansas for their support on this project. Support was also provided by the Arkansas SURF. This material is based upon work supported by the National Science Foundation Graduate Research Fellowship under Grant No. 12259. Any opinion, findings, and conclusions or recommendations expressed in this material are those of the authors(s) and do not necessarily reflect the views of the National Science Foundation.

\section{Nomenclature}

EDI Electrodeionization

$\mathrm{N} \quad$ Number of Cells

RED Reverse Electrodialysis 


$\begin{array}{ll}\text { REDI } & \text { Reverse Electrodeionization } \\ \mathrm{R}_{\text {cell }} & \text { Cell Resistance } \\ \mathrm{R}_{\text {electrode }} & \text { Electrode Resistance } \\ \mathrm{R}_{\text {load }} & \text { Load Resistance } \\ \mathrm{R}_{\text {total }} & \text { Total Stack Resistance } \\ \mathrm{V}_{\text {applied }} & \text { Applied Voltage } \\ \mathrm{V}_{\text {cell pair }} & \text { Voltage Generated per Cell Pair }\end{array}$

\section{References}

[1] J.W. Post, J. Veerman, H.V.M. Hamelers, G.J.W. Euverink, S.J. Metz, K. Nymeijer, et al., Salinity-gradient power: Evaluation of pressure-retarded osmosis and reverse electrodialysis, J. Memb. Sci. 288 (2007) 218-230. doi:10.1016/j.memsci.2006.11.018.

[2] N.Y. Yip, M. Elimelech, Thermodynamic and energy efficiency analysis of power generation from natural salinity gradients by pressure retarded osmosis., Environ. Sci. Technol. 46 (2012) 5230-9. doi:10.1021/es300060m.

[3] J.W. Post, Blue Energy : electricity production from salinity gradients by reverse electrodialysis, Wageningen University, 2009.

[4] J.W. Post, H.V.M. Hamelers, C.J.N. Buisman, Energy recovery from controlled mixing salt and fresh water with a reverse electrodialysis system, Environ. Sci. Technol. 42 (2008) 5785-5790. doi:10.1021/es8004317.

[5] G.Z. Ramon, B.J. Feinberg, E.M. V. Hoek, Membrane-based production of salinitygradient power, Energy Environ. Sci. 4 (2011) 4423-4434. doi:10.1039/c1ee01913a.

[6] D. a Vermaas, D. Kunteng, M. Saakes, K. Nijmeijer, Fouling in reverse electrodialysis under natural conditions., Water Res. 47 (2013) 1289-98. doi:10.1016/j.watres.2012.11.053.

[7] D. a Vermaas, M. Saakes, K. Nijmeijer, Doubled power density from salinity gradients at reduced intermembrane distance., Environ. Sci. Technol. 45 (2011) 7089-95. doi:10.1021/es2012758.

[8] J. Veerman, M. Saakes, S.J. Metz, G.J. Harmsen, Electrical power from sea and river water by reverse electrodialysis: A first step from the laboratory to a real power plant, Environ. Sci. Technol. 44 (2010) 9207-9212. doi:10.1021/es1009345. 
[9] P. Długołęcki, A. Gambier, K. Nijmeijer, M. Wessling, Practical potential of reverse electrodialysis as process for sustainable energy generation, Environ. Sci. Technol. 43 (2009) 6888-6894. doi:10.1021/es9009635.

[10] J. Veerman, M. Saakes, S.J. Metz, G.J. Harmsen, Reverse electrodialysis: Performance of a stack with 50 cells on the mixing of sea and river water, J. Memb. Sci. 327 (2009) 136144. doi:10.1016/j.memsci.2008.11.015.

[11] R.D. Vidic, S.L. Brantley, J.M. Vandenbossche, D. Yoxtheimer, J.D. Abad, Impact of shale gas development on regional water quality., Science. 340 (2013) 1235009. doi:10.1126/science.1235009.

[12] M. Elimelech, W. a Phillip, The future of seawater desalination: energy, technology, and the environment., Science. 333 (2011) 712-717. doi:10.1126/science.1200488.

[13] H.R. Acharya, C. Henderson, H. Matis, H. Kommepalli, B. Moore, H. Wang, Cost effective recovery of low-TDS frac flowback water for re-use, US Dep. Energy Washington, DC. (2011).

[14] S. Pawlowski, P. Sistat, J.G. Crespo, S. Velizarov, Mass Transfer in Reverse Electrodialysis: Flow Entrance Effects and Diffusion Boundary Layer Thickness, J. Memb. Sci. 471 (2014) 72-83. doi:10.1016/j.memsci.2014.07.075.

[15] J. Veerman, R.M. de Jong, M. Saakes, S.J. Metz, G.J. Harmsen, Reverse electrodialysis: Comparison of six commercial membrane pairs on the thermodynamic efficiency and power density, J. Memb. Sci. 343 (2009) 7-15. doi:10.1016/j.memsci.2009.05.047.

[16] R.D. Cusick, Y. Kim, B.E. Logan, Energy Capture from Thermolytic Solutions in Microbial Reverse-Electrodialysis Cells, Science (80-. ). 335 (2012) 1474-1477. doi:10.1126/science.1219330.

[17] K.S. Kim, W. Ryoo, M.-S. Chun, G.-Y. Chung, Simulation of enhanced power generation by reverse electrodialysis stack module in serial configuration, Desalination. 318 (2013) 79-87. doi:10.1016/j.desal.2013.03.023.

[18] R. Banan Sadeghian, O. Pantchenko, D. Tate, A. Shakouri, Miniaturized concentration cells for small-scale energy harvesting based on reverse electrodialysis, Appl. Phys. Lett. 99 (2011) 99-101. doi:10.1063/1.3656279.

[19] P. Dlugolecki, J. Dabrowska, K. Nijmeijer, M. Wessling, Ion conductive spacers for increased power generation in reverse electrodialysis.pdf, J. Memb. Sci. 347 (2010) 101107.

[20] D. a. Vermaas, M. Saakes, K. Nijmeijer, Power generation using profiled membranes in reverse electrodialysis.pdf, J. Memb. Sci. 385-386 (2011) 234-242. 
[21] J. Liu, G.M. Geise, X. Luo, H. Hou, F. Zhang, Y. Feng, et al., Patterned ion exchange membranes for improved power production in microbial reverse-electrodialysis cells, J. Power Sources. 271 (2014) 437-443. doi:10.1016/j.jpowsour.2014.08.026.

[22] J. Balster, D.F. Stamatialis, M. Wessling, Membrane with integrated spacer, J. Memb. Sci. 360 (2010) 185-189. doi:10.1016/j.memsci.2010.05.011.

[23] J. Balster, D.F. Stamatialis, M. Wessling, Towards spacer free electrodialysis, J. Memb. Sci. 341 (2009) 131-138. doi:10.1016/j.memsci.2009.05.048.

[24] P. Długołecki, B. Anet, S.J. Metz, K. Nijmeijer, M. Wessling, Transport limitations in ion exchange membranes at low salt concentrations, J. Memb. Sci. 346 (2010) 163-171. doi:10.1016/j.memsci.2009.09.033.

[25] P. Długołecki, P. Ogonowski, S.J. Metz, M. Saakes, K. Nijmeijer, M. Wessling, On the resistances of membrane, diffusion boundary layer and double layer in ion exchange membrane transport, J. Memb. Sci. 349 (2010) 369-379. doi:10.1016/j.memsci.2009.11.069.

[26] T. Ho, A. Kurup, T. Davis, J. Hestekin, Wafer Chemistry and Properties for Ion Removal by Wafer Enhanced Electrodeionization, Sep. Sci. Technol. 45 (2010) 433-446. doi:10.1080/01496390903526709.

[27] A.S. Kurup, T. Ho, J. a. Hestekin, Simulation and Optimal Design of Electrodeionization Process: Separation of Multicomponent Electrolyte Solution, Ind. Eng. Chem. Res. 48 (2009) 9268-9277. doi:10.1021/ie801906d.

[28] S. Datta, Y.J. Lin, D.J. Schell, C.S. Millard, S.F. Ahmad, M.P. Henry, et al., Removal of acidic impurities from corn stover hydrolysate liquor by resin wafer based electrodeionization, Ind. Eng. Chem. Res. 52 (2013) 13777-13784. doi: $10.1021 /$ ie 4017754 .

[29] B.G. Rahm, J.T. Bates, L.R. Bertoia, A.E. Galford, D. a. Yoxtheimer, S.J. Riha, Wastewater management and Marcellus Shale gas development: Trends, drivers, and planning implications, J. Environ. Manage. 120 (2013) 105-113. doi:10.1016/j.jenvman.2013.02.029.

[30] W.L. Ellsworth, Injection-Induced Earthquakes, Science (80-. ). 341 (2013) 1-7.

[31] W. Gan, C. Frohlich, Gas injection may have triggered earthquakes in the Cogdell oil field, Texas., Proc. Natl. Acad. Sci. U. S. A. 110 (2013) 18786-91. doi:10.1073/pnas.1311316110.

[32] N. van der Elst, H.M. Savage, K.M. Keranen, G.A. Abers, Enhanced Remote Earthquake Triggering at Fluid-Injection Sites in the Midwestern United States, Science (80-. ). 341 (2013) 164-167. 
[33] H. Meng, C. Peng, S. Song, D. Deng, Electro-regeneration mechanism of ion-exchange resins in electrodeionization, Surf. Rev. Lett. 11 (2004) 599-605.

[34] D. a. Vermaas, E. Guler, M. Saakes, K. Nijmeijer, Theoretical power density from salinity gradients using reverse electrodialysis, Energy Procedia. 20 (2012) 170-184. doi:10.1016/j.egypro.2012.03.018.

[35] B. Freeman, Engineers improve recycling system used in fracking to save water and energy, Membr. Technol. 2013 (2013) 7.

[36] D.J. Miller, X. Huang, H. Li, S. Kasemset, A. Lee, D. Agnihotri, et al., Fouling-resistant membranes for the treatment of flowback water from hydraulic shale fracturing: A pilot study, J. Memb. Sci. 437 (2013) 265-275. doi:10.1016/j.memsci.2013.03.019.

[37] P. Chiesa, M. Alstofi, A. Giaffrida, Blue Energy: Salinity Gradient for Energy Conversion, in: Process Intensif. Sustain. Energy Convers., 2015: pp. 267-298. 


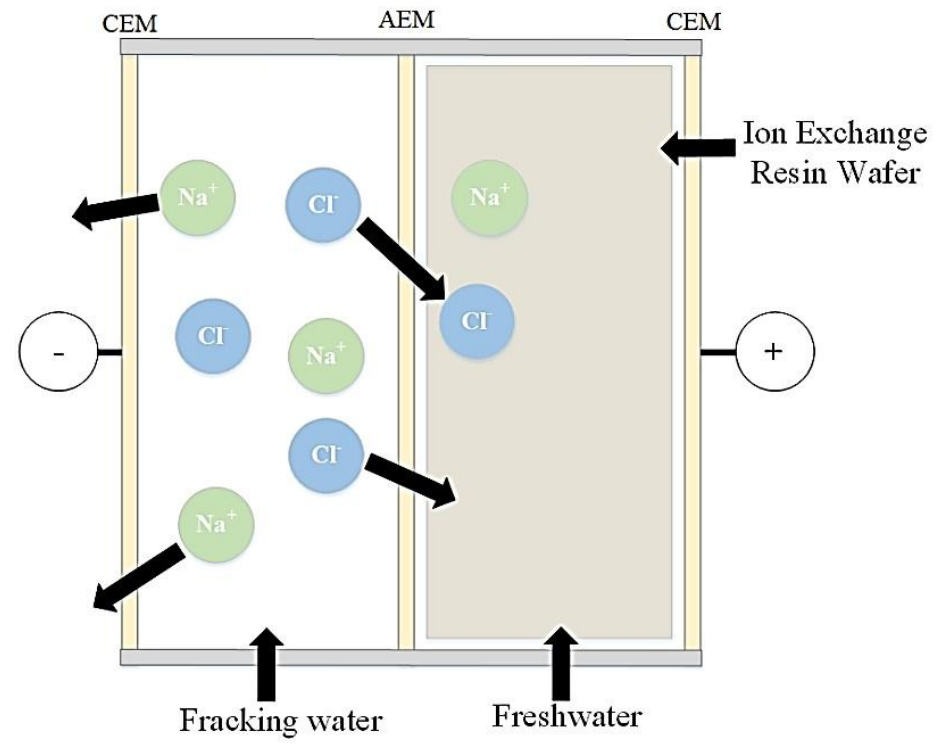




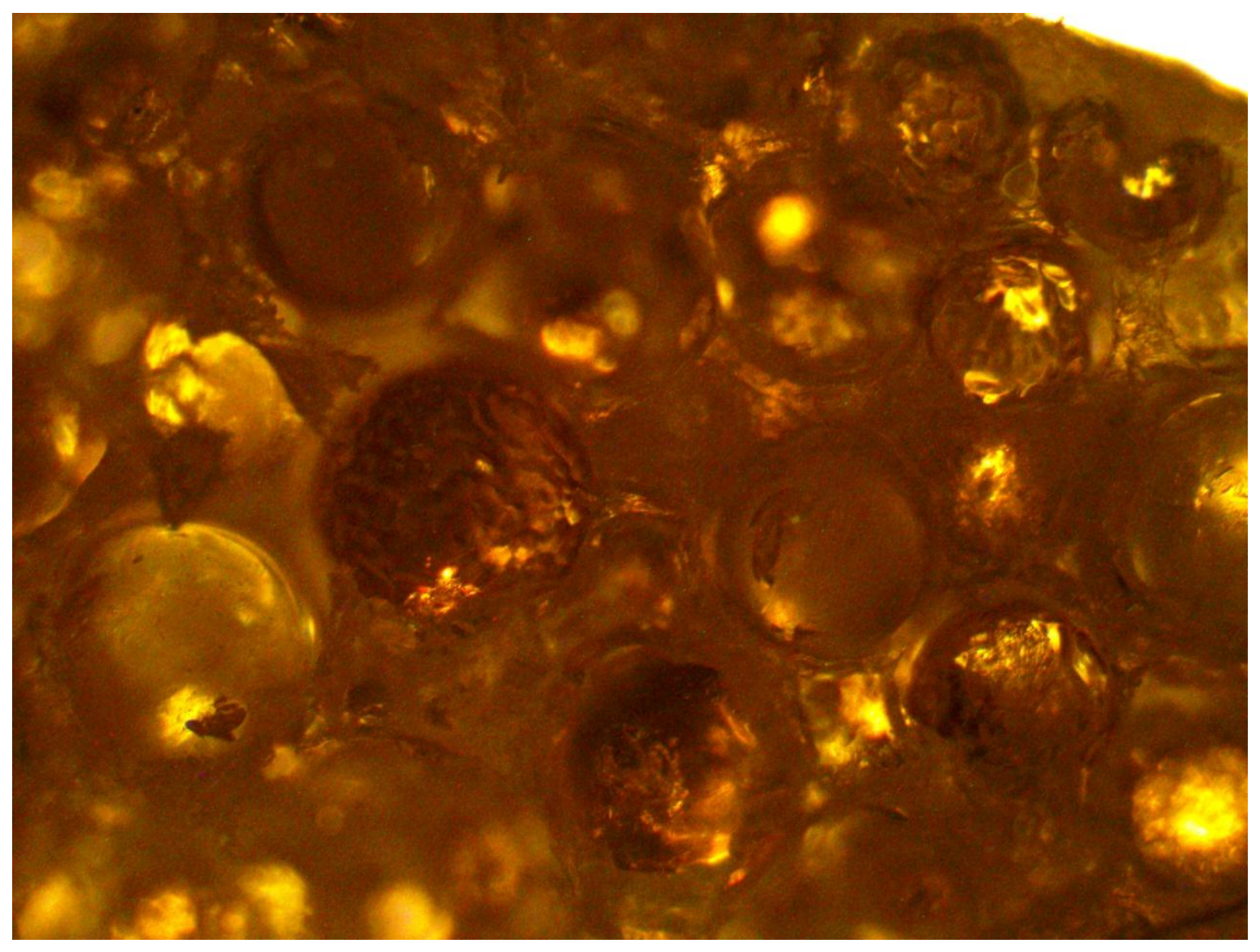




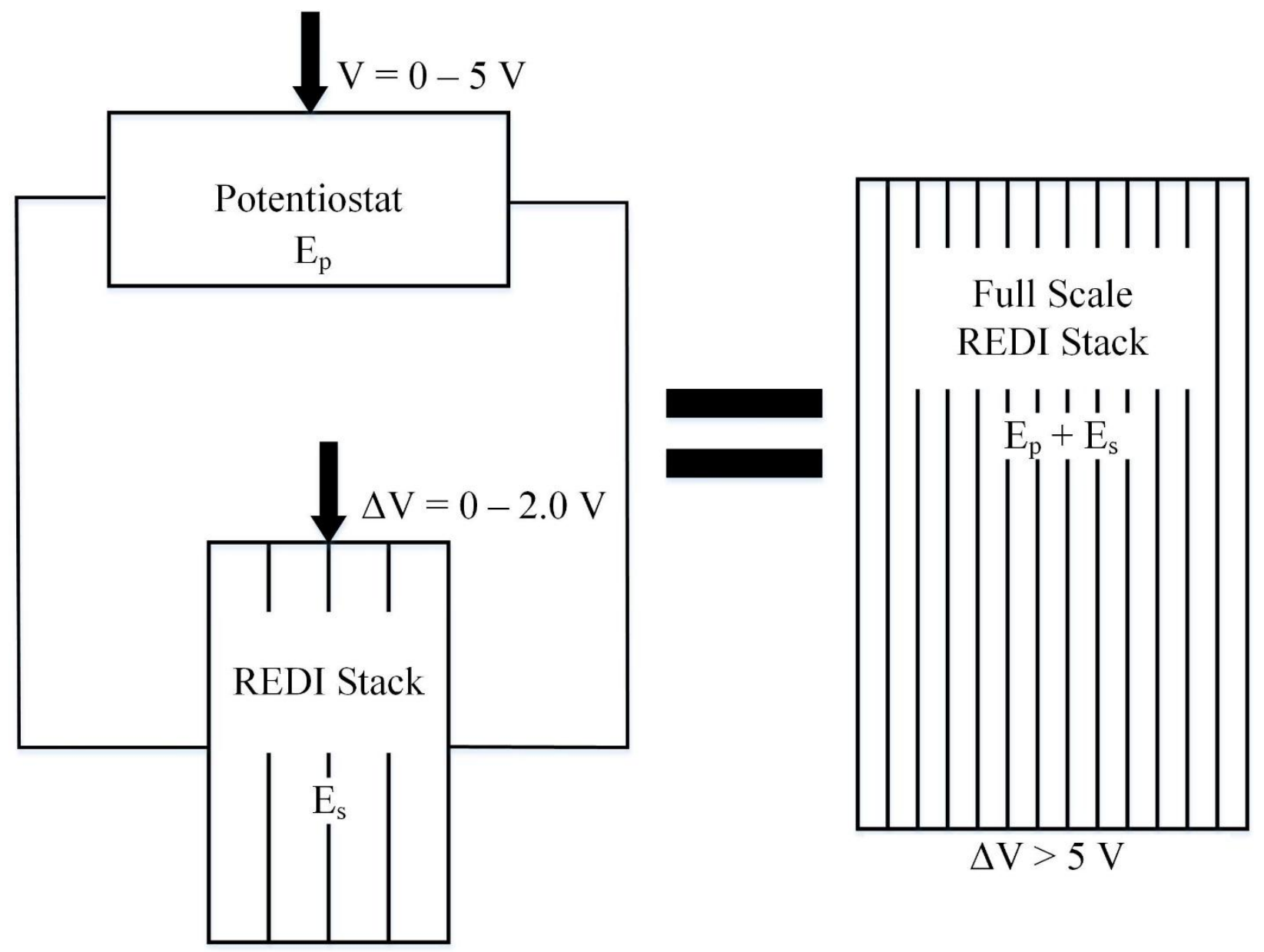




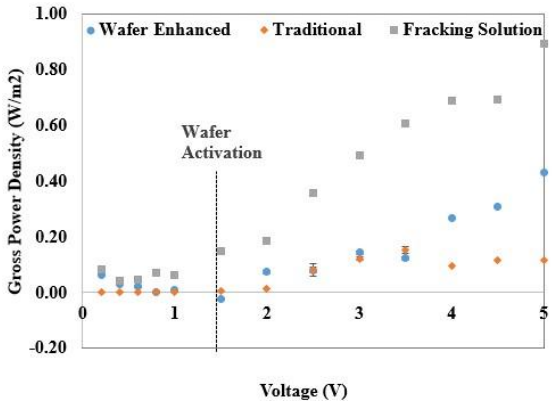




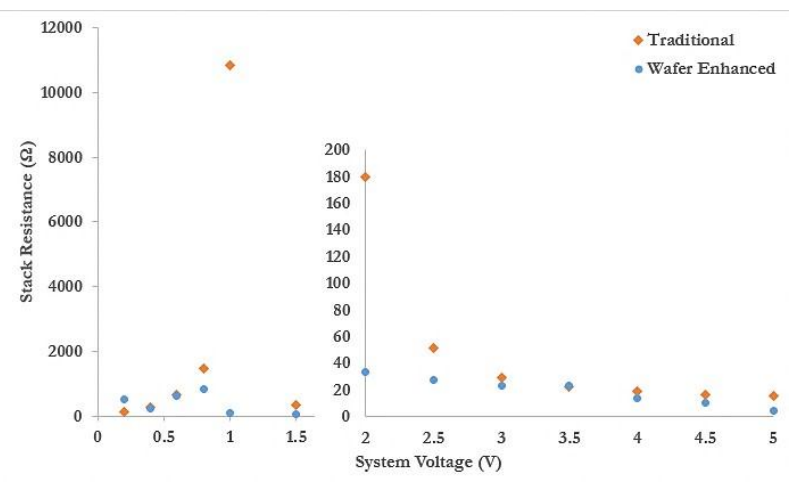




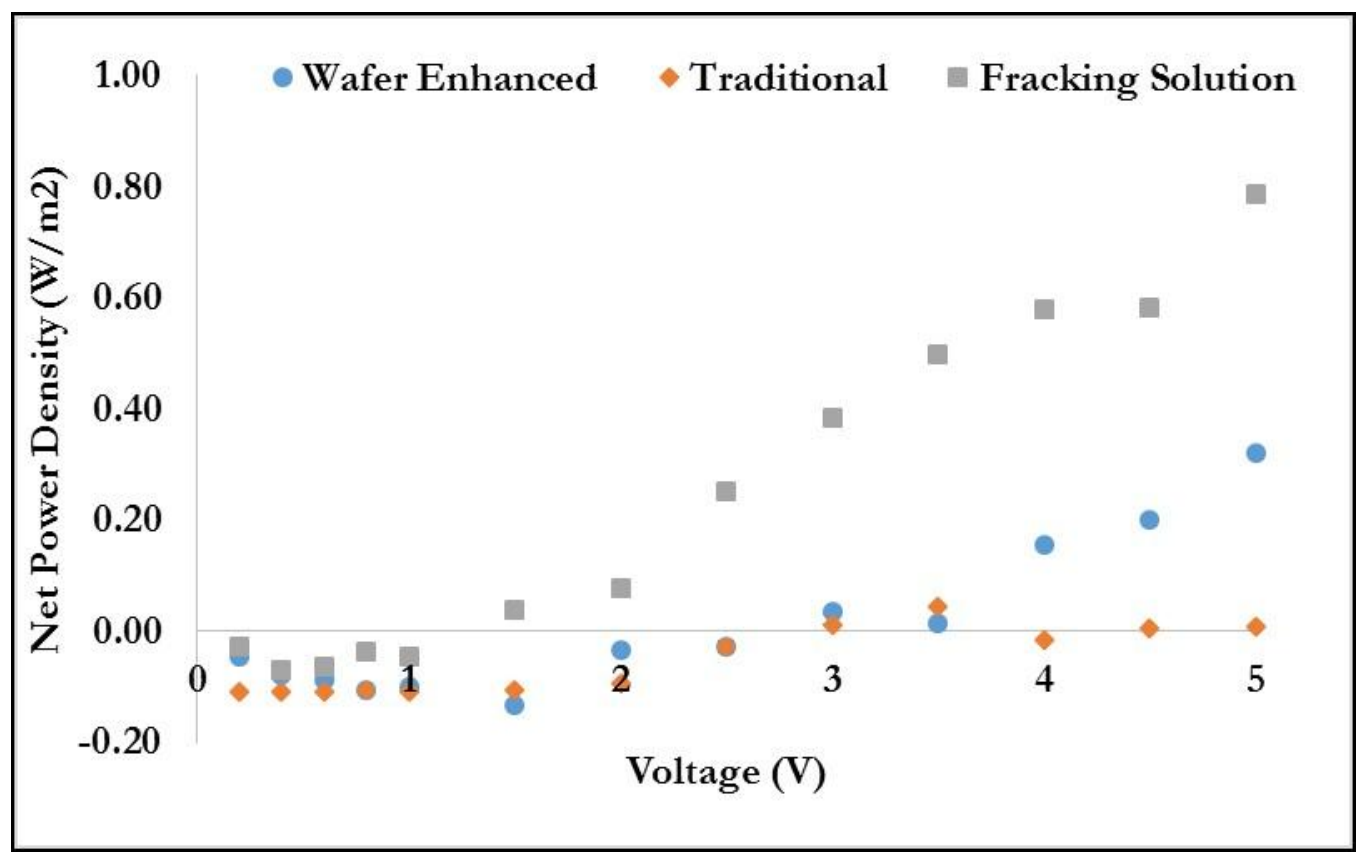




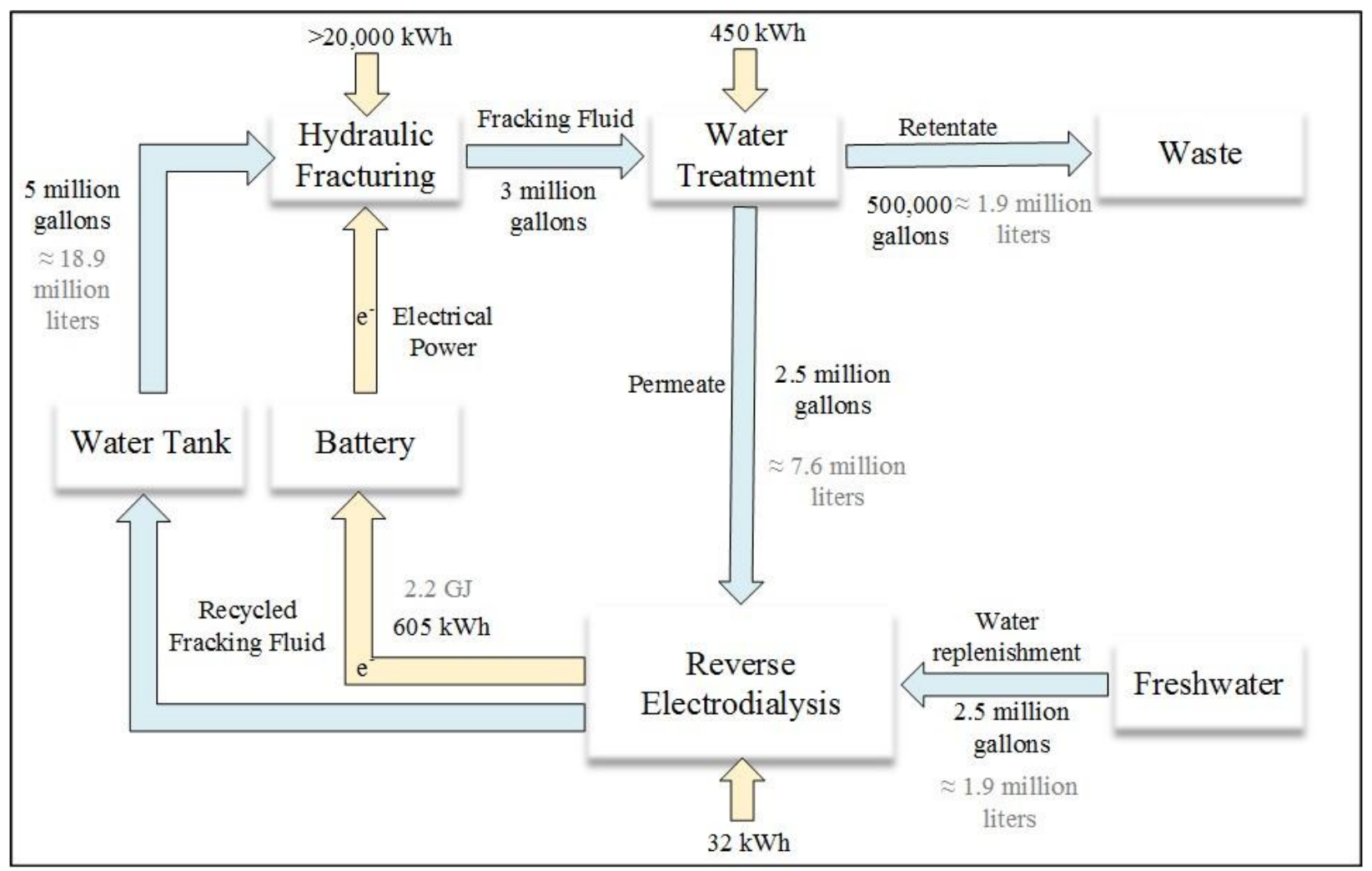




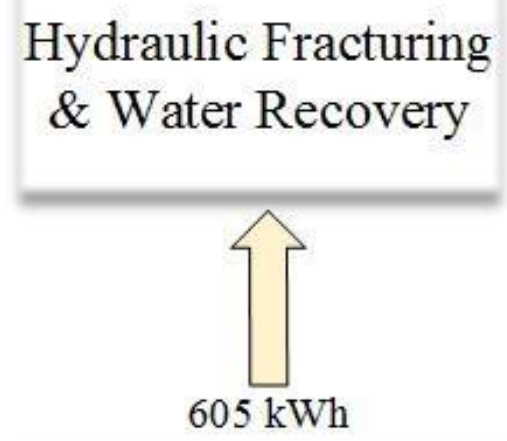

Fracking Fluid

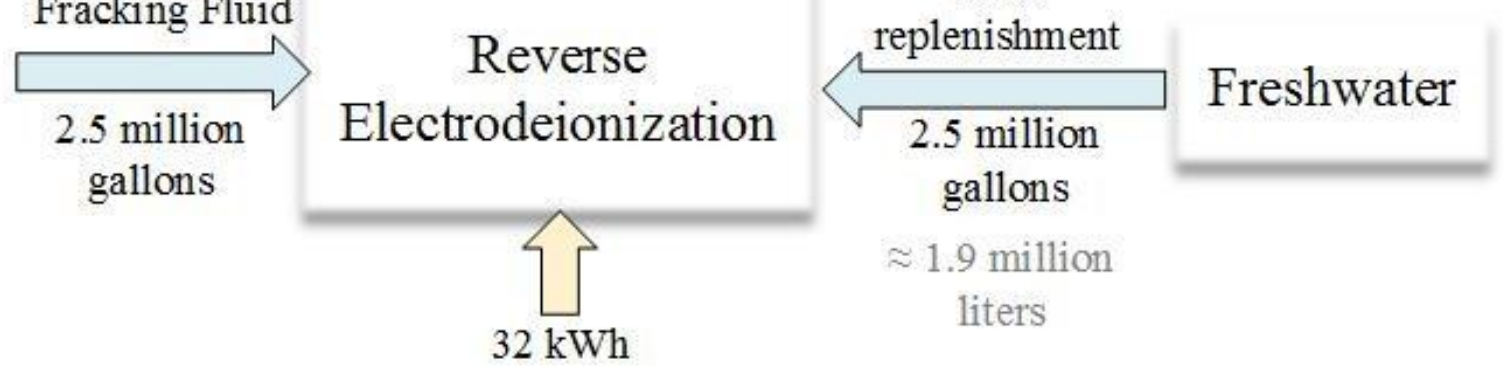

Water 